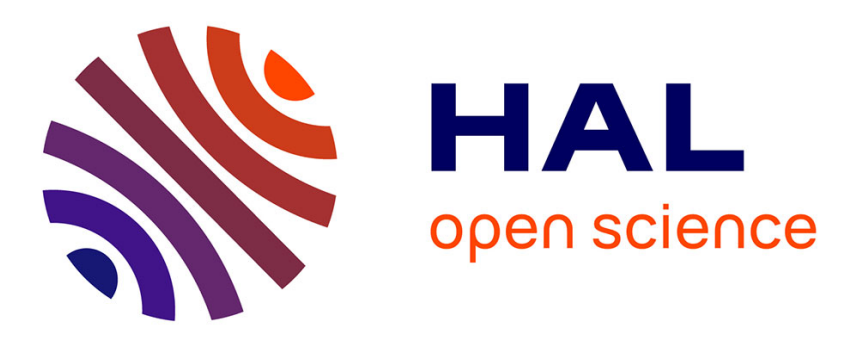

\title{
Biocontrol of eyespot disease on two winter wheat cultivars by an anecic earthworm (Lumbricus terrestris)
}

Michel Bertrand, Manuel Blouin, Sébastien Barot, Aude Charlier, Damien Marchand, Jean Roger-Estrade

\section{- To cite this version:}

Michel Bertrand, Manuel Blouin, Sébastien Barot, Aude Charlier, Damien Marchand, et al.. Biocontrol of eyespot disease on two winter wheat cultivars by an anecic earthworm (Lumbricus terrestris). Applied Soil Ecology, 2015, 96, pp.33 - 41. 10.1016/j.apsoil.2015.07.006 . hal-01241050

\author{
HAL Id: hal-01241050 \\ https://hal.science/hal-01241050
}

Submitted on 9 Dec 2015

HAL is a multi-disciplinary open access archive for the deposit and dissemination of scientific research documents, whether they are published or not. The documents may come from teaching and research institutions in France or abroad, or from public or private research centers.
L'archive ouverte pluridisciplinaire HAL, est destinée au dépôt et à la diffusion de documents scientifiques de niveau recherche, publiés ou non, émanant des établissements d'enseignement et de recherche français ou étrangers, des laboratoires publics ou privés. 


\title{
Biocontrol of eyespot disease on two winter wheat cultivars by an anecic earthworm (Lumbricus terrestris)
}

\author{
Michel Bertrand ${ }^{\mathrm{a}, \mathrm{b}}$, Manuel Blouin ${ }^{\mathrm{c}}$, Sébastien Barot ${ }^{\mathrm{d}}$, Aude Charlier ${ }^{\mathrm{a}, \mathrm{b}}$, \\ Damien Marchand ${ }^{\mathrm{a}, \mathrm{b}}$, Jean Roger-Estrade ${ }^{\mathrm{a}, \mathrm{b}, *}$ \\ a INRA, UMR211 Agronomie, F-78850 Thiverval-Grignon, France \\ ${ }^{\mathrm{b}}$ AgroParisTech, UMR211 Agronomie, F-78850 Thiverval-Grignon, France \\ ' Institute of Ecology and Environmental Sciences - Paris (IRD, CNRS, UPMC, UPEC), UPEC, 61 avenue du Général De Gaulle, 94010 Créteil cedex, France \\ d IRD, IEES-P (IRD, CNRS, UPMC, UPEC), ENS, 46 Rue d'Ulm, 75230 Paris cedex, France
}

A R T I C L E I N F O

\section{Article history:}

Received 12 March 2015

Received in revised form 3 July 2015

Accepted 7 July 2015

Available online 25 July 2015

\section{Keywords:}

Belowground-aboveground interactions

Anecic earthworm Lumbricus terrestris

Biological control

Eyespot disease

Pathogenic fungus Oculimacula yallundae

Winter wheat Triticum aestivum

\begin{abstract}
A B S T R A C T
Eyespot is a major fungal disease of winter wheat, mostly affecting the base of the stem. The development of biological control approaches, using organisms such as earthworms, represents a potential alternative strategy for eyespot control. In a greenhouse experiment, we analyzed the response of two wheat cultivars (Soissons and Aubusson) to the presence of the pathogenic fungus Oculimacula yallundae and the anecic earthworm Lumbricus terrestris, alone and in combination. We assessed necrosis frequency, necrosis severity, wheat biomass, resource allocation and soil mineral concentrations. Disease incidence was lower in the presence of earthworms: the frequency of necrosis was $44 \%$ lower for Soissons and $70 \%$ lower for Aubusson. Necrosis severity was also lower for both cultivars (50\% lower for Soissons and $80 \%$ lower for Aubusson) in the presence of earthworms. Earthworms had no detectable effect on the shoot and root biomasses of plants exposed to the fungus, but they modified resource allocation between plant organs and nutrient translocation within the plant. Our results suggest that earthworms are a potentially effective biocontrol agent for eyespot, and we discuss the possible underlying mechanisms.
\end{abstract}

(c) 2015 Elsevier B.V. All rights reserved.

\section{Introduction}

Over the last 20 years, studies of belowground-aboveground interactions (Hooper et al., 2000) have greatly modified our vision of soil function and plant growth. The underlying mechanisms are increasingly understood, but the potential of this complex feedback system has not yet been fully exploited in agriculture. The sustainability of agriculture could be improved by effective management of belowground-aboveground feedback in the field (Hooper et al., 2000; Wardle et al., 2004; Bardgett et al., 2005). This might allow the replacement of chemical inputs with ecological processes, in the framework of agro-ecology (Altieri, 1989) or ecological engineering (Barot et al., 2012). In this respect, the biocontrol of crop diseases is a key opportunity.

Eyespot, a fungal disease caused by Oculimacula yallundae (s yn. Tapesia yallundae), previously known as Pseudocercosporella herpotrichoïdes), remains problematic even in conventional agriculture and may decrease yield by up to 40\% (Meyer et al., 2011). 0 .

\footnotetext{
* Corresponding author at: INRA UMR 211 Agronomie, F-78850 ThivervalGrignon, France. Tel.: +336881318 16 .

E-mail address: estrade@grignon.inra.fr (J. Roger-Estrade).
}

yallundae is an ascomycete that causes necrosis at the stem base, thereby impairing the uptake of nutrients and increasing the risk of lodging at the end of the crop cycle. The mycelium survives on crop residues, and plants are contaminated by spores transported in the water film present on the soil surface after rain (Matusinsky et al., 2009) or via conidia disseminated by wind and rain splash. The main control methods, in addition to chemical fungicides and the use of resistant cultivars, are the limitation of disease incidence through the use of a diversified crop rotation, the burial of crop residues and cropping practices favoring the rapid infiltration of water into the soil (Colbach et al., 1999).

Biological processes in the soil may also help to control pathogenic fungi, as shown in several studies. For example, litter ingestion by Lumbricus terrestris decreases attacks by Venturia inaequalis, an ascomycete responsible for apple scab (Hirst and Stedman, 1962). Wolfarth et al. (2011) showed that the presence of L. terrestris decreased the incidence of fungal disease due to Fusarium culmorum on winter wheat crops. This effect was attributed to the burial of infected residues by the worm. The presence of earthworms (genus Apporectodea) has been shown to decrease attack rates for two soil-borne fungal diseases: Rhizoctonia bare patch, caused by Rhizoctonia solani (Stephens et al., 1993; 
Stephens and Davoren, 1997) and take-all, caused by Gaeumannomyces graminis var. tritici (Stephens et al., 1994). This control of fungal pathogens by earthworms may reflect the important contribution of microorganisms to the diet of earthworms, which prefer fungi to bacteria (Shan et al., 2013). Moreover several studies (e.g., Bonkowski et al., 2000) have suggested that earthworms may feed selectively on fungi, with pathogenic fungi preferred over non-pathogenic fungi.

We hypothesized that similar mechanisms might underlie the biological control of eyespot, caused by 0 . yallundae, by the earthworm $L$. terrestris. Indeed, the burial of crop residues and the rapid infiltration of water into soil are two processes stimulated by anecic earthworms (Bouché and Al-Addan, 1997). Moreover, many studies have shown that earthworms have a positive effect on plant growth (Brown et al., 1999; Scheu, 2003; Van Groenigen et al., 2014), which might improve plant resistance to disease. We hypothesized that these effects might also result in a lower incidence of eyespot in the presence of earthworms. The mechanisms underlying this control of parasite incidence in the presence of earthworms may involve indirect effects due to improvements in the nutritional status of the plant in the presence of earthworms (Whalen and Parmelee, 2000) or direct effects on plant defense mechanisms and the induction of induced systemic resistance (Puga-Freitas et al., 2012b; Puga-Freitas and Blouin, 2015).

We set up a greenhouse experiment, carried out in microcosms, in which two wheat cultivars were inoculated with eyespot in the presence or absence of $L$. terrestris earthworms. The frequency and severity of stem necrosis were recorded. We also monitored plant growth and development by analyzing (i) the morphology of plant above- and below-ground organs, (ii) resource allocation between the various organs and (iii) tissue $\mathrm{N}$ content. We also assessed soil $\mathrm{C}, \mathrm{N}$ and $\mathrm{P}$ availability for the different treatments.

We addressed the following specific questions: (1) Do earthworms decrease the frequency and severity of the disease? (2) Do they decrease the negative impact of the disease on wheat biomass? (3) Are the effects of earthworms robust enough to be observed on both cultivars?

\section{Materials and methods}

\subsection{Experimental treatments}

We used four experimental treatments for each cultivar: C: control, without earthworms or fungus; E: earthworms (no fungus); F: fungus (no earthworms); EF: earthworms and fungus.

The experiment was set up as a randomized block design with three factors (earthworms, fungus and cultivar type) and eight replicates for each of the eight treatments, for a total of 64 microcosms.

\subsection{Soil, earthworms, plant material and fungal inoculum}

Plastic pots $(25 \mathrm{~cm}$ high, $9 \mathrm{~cm}$ in diameter) were filled with $0.8 \mathrm{~kg}$ of soil from the $0-30 \mathrm{~cm}$ surface layer of a field that had been under maize (Zea mais) monoculture for 10 years. This plot was chosen as the soil source because maize does not serve as a host for eyespot; the soil from this plot was, therefore, probably free of this pathogen. The soil was air-dried and sieved through a 2-mm meshsize sieve, to eliminate earthworm cocoons. The mean characteristics of the $0-30 \mathrm{~cm}$ surface layer of the soil were as follows: $1.3 \mathrm{~g} \mathrm{~cm}^{-3}$ bulk density, $\mathrm{pH} \mathrm{KCl:} \mathrm{7.1,} \mathrm{clay:} 288 \mathrm{~g} \mathrm{~kg}^{-1}$, silt: $547 \mathrm{~g} \mathrm{~kg}^{-1}$, sand: $165 \mathrm{~g} \mathrm{~kg}^{-1}$, organic C: $27.4 \mathrm{~g} \mathrm{~kg}^{-1}$, total $\mathrm{N}$ : $1.26 \mathrm{~g} \mathrm{~kg}^{-1}$, total $\mathrm{CaCO}_{3}: 85.6 \mathrm{~g} \mathrm{~kg}^{-1}$.

Anecic earthworms ( $L$. terrestris) were purchased from Le Thepault Fils (Montlhery, France). They were kept in soil containers at $4{ }^{\circ} \mathrm{C}$ for two weeks. The earthworms were then purged, cleaned and weighed. Four days after sowing, two earthworms, with a mean fresh weight of $3.43( \pm 0.30) \mathrm{g}$, were added to each microcosm. This density is commonly used in microcosm experiments (e.g., Laossi et al., 2010; Sizmur et al., 2011). Earthworms were overfed four times during the experiment, with $0.80 \mathrm{~g}$ of dehydrated alfalfa, to ensure optimal growing conditions. The same amount of alfalfa was also added, on the same dates, to the pots of treatments without earthworms. Wheat seeds, Triticum aestivum, from two cultivars of similar earliness, were purchased from the seed companies Florimond Deprez (cv Soissons) and Nickerson (cv Aubusson). Seeds were stored at $4{ }^{\circ} \mathrm{C}$ for 44 days. Five germinated wheat seeds were introduced into each pot. Thirty days after sowing, the number of seedlings per pot was reduced to three. Pots were placed in a greenhouse with a 16-hour photoperiod. The temperature thresholds applied were $10^{\circ} \mathrm{C}$ and $9{ }^{\circ} \mathrm{C}$ for activating the cooling system during the day and night, respectively, and $16^{\circ} \mathrm{C}$ and $15^{\circ} \mathrm{C}$ for activating the heating system during the day and night, respectively. During the experiment, the temperature remained between $10^{\circ} \mathrm{C}$ and $25^{\circ} \mathrm{C}$. Microcosms were watered regularly, to keep soil water content at about $80 \%$ of field capacity. Fertilizer $\left(33.5 \% \mathrm{NH}_{4} \mathrm{NO}_{3}\right)$ was supplied to all the microcosms at the tillering stage $\left(0.07 \mathrm{~g} \mathrm{~N} \mathrm{pot}^{-1}\right)$ and at ear formation $\left(0.21 \mathrm{~N} \mathrm{pot}^{-1}\right)$, to provide plants with an amount of nitrogen calculated from a dose commonly provided in wheat fields $\left(240 \mathrm{~kg} \mathrm{~N} \mathrm{ha}^{-1}\right)$. The experiment was terminated at flowering, 119 days after sowing, on April 4th.

The eyespot inoculum was provided by GEVES (Groupe d'Etude et de contrôle des Variétés et des Semences, Rennes, France), the national seed evaluation agency (Angers, France), on autoclaved infested barley grains. In the treatments with fungus (F and EF), three crushed inoculated barley grains were placed on the soil surface, 8,37 and 65 days after sowing. Water was supplied during the first five days after inoculation to favor fungus development. For the $\mathrm{C}$ and $\mathrm{E}$ treatments, we added three non infested crushed barley grains without fungus to each pot.

\subsection{Measurements}

At the end of the experiment, the frequency of necrosis was determined as the proportion of plants with at least one necrotic lesion. For each plant, we scored necrosis severity with a four-class visual index, based on the proportion of the stem section destroyed by the fungus: $0=$ no attack; $1=$ less than $1 / 3$ of the stem section destroyed, $2=$ between $1 / 3$ and $2 / 3$ of the stem section destroyed, $3=$ more than $2 / 3$ of the stem section destroyed. If several attacks were observed on the same plant, only the score for the most severe necrotic lesion was noted. Plant height, total number of tillers and leaf area index (LAI), determined with the LI 3100 planimeter (Li-Cor, USA), were measured for each of the three plants in each microcosm.

The main stem, secondary tillers and ears were separated, ovendried at $80^{\circ} \mathrm{C}$ for 2 days and the dry biomass was recorded. Roots were carefully washed, cut into small pieces and passed through a sieve column (Blouin et al., 2007a). Diameter classes displaying similar types of variation were grouped together, resulting in two final classes: $<$ and $>400 \mu \mathrm{m}$ in diameter.

Oven-dried roots, leaves and shoots were pooled and nitrogen concentrations were determined, according to the Dumas combustion procedure (Houba et al., 1990).

Earthworms were recovered and weighed, and cocoons were counted. In each pot, the total $\mathrm{N}$ content of $80 \mathrm{~g}$ oven-dried $\left(80^{\circ} \mathrm{C}\right.$ for $72 \mathrm{~h}$ ) soil samples was determined by a dry combustion procedure (NFISO 13878). Organic C content was determined by Anne's method (Anne, 1945), by colorimetry with potassium bichromate after oxidization of the soil organic matter with sulphuric acid at $135^{\circ} \mathrm{C}$. Soil nitrate and ammonium contents were determined by 
spectrocolorimetry, after extraction in a solution of $0.5 \mathrm{~N} \mathrm{KCl}$. The available $\mathrm{P}$ content of the soil was determined by the Olsen method (NF ISO 11,263) on $80 \mathrm{~g}$ soil samples air-dried for $96 \mathrm{~h}$.

\subsubsection{Statistical analysis}

We carried out analyses of variances, assessing the effects of the presence/absence of earthworms, presence/absence of fungal inoculation and cultivar. We initially included all two- and three-way interactions between these factors in the model, but the model was then simplified: non-significant three-way interactions were removed, and if no three-way interactions were significant, non-significant two-way interactions were also removed. Non-destructive measurements repeated on the different individuals within each pot were not independent. A mixed model was thus used, including a random effect of the pot. In this case, we calculated the marginal $R^{2}$ (Nakagawa et al., 2013) rather than the standard $R^{2}$. The directions of effects were determined by parameter estimation.

We analyzed the frequency of necrosis, by applying the same mixed model, with a binomial error. As the residuals of the model of the visual index of necrosis severity were not normally distributed and their variance was not uniform across treatments, we checked the results obtained with this model by carrying out Kruskal-Wallis tests. All statistical analyses were carried out with R software (R Development Core Team, 2010).

\section{Results}

\subsection{Earthworm growth and survival}

We were able to recover $74 \%$ of the earthworms at the end of the experiment and both earthworms died in only one pot. The total biomass of earthworms increased by $41 \%$ in the microcosms from which two individuals were recovered. Furthermore, on average, each individual produced 2.7 cocoons during the experiment.

\subsection{Eyespot incidence}

The frequency and severity of eyespot necrosis were affected by the presence of the fungus (Table 1 and Fig. 1). Our inoculation treatment therefore had an effect on wheat. In the absence of inoculation, the incidence of the disease was low, with almost no contamination from naturally occurring spores of the fungus

\section{Table 1}

Analysis of the frequency of fungal disease and its severity. For disease severity, we used a standard mixed model including the pot effect as a random effect and the $F$ values are displayed. For disease frequency, the same mixed model was used, but with a binomial error. In this case $z$ values are displayed. The directions of effects are indicated: E, presence of earthworms; $\mathrm{nE}$, absence of earthworms; $\mathrm{F}$, inoculation with fungus; nF, absence of fungus; A, cv Aubusson; S; cv Soissons. The last row gives the marginal $R^{2}$ for severity. The total number of degrees of freedom is 192 . denotes interactions removed from the model because they were not significant.

\begin{tabular}{lll}
\hline Factor & Frequency $(z$ values $)$ & Severity $(F$ values $)$ \\
\hline Cultivar & $-2.51^{*}$ & $14.62^{* * *}$ \\
Earthworm & $1.93^{*}$ & $8.49^{* *}$ \\
Fungus & $-4.59^{* * *}$ & $55.75^{* * *}$ \\
Earthworm X fungus & - & $14.62^{* * *}$ \\
Fungus X cultivar & - & $10.74^{* *}$ \\
Direction of effects & $\mathrm{S}>\mathrm{A}$ & $\mathrm{S}>\mathrm{A}$ if $\mathrm{F}$ \\
& $\mathrm{nE}>\mathrm{E}$ & $\mathrm{nE}>\mathrm{E}$ if $\mathrm{F}$ \\
$R^{2}$ & $\mathrm{~F}>\mathrm{nF}$ & 0.35 \\
\hline
\end{tabular}

${ }^{*} P<0.05$.

${ }^{* *} P<0.01$.

$P<0.001$ (necrosis frequency below 5\%, on average, for the non-inoculated treatments).

The fungal disease was affected by the presence of earthworms (Fig. 1 and Table 1). The frequency of necrosis after inoculation was much lower in the presence of earthworms, decreasing from $75 \%$ for treatment $\mathrm{F}$ to $42 \%$ for treatment $\mathrm{EF}$ treatment for Soissons, and from $46 \%$ (F) to $14 \%$ (EF) for Aubusson (Fig. 1A). Soissons was more frequently affected by eyespot disease than Aubusson. However, the interaction between the presence of earthworms and cultivar was not significant (Table 1 ), indicating that the decrease in disease frequency due to the presence of earthworms (F vs. EF) was similar for both cultivars. Furthermore the difference in necrosis frequency between Aubusson and Soissons ( $F$ treatment for A vs $\mathrm{F}$ treatment for $\mathrm{S}$ ) was similar to the difference in necrosis frequency induced by the presence of earthworms ( $F$ vs EF treatments for each cultivar).

Disease severity was higher in the absence of earthworms (F) than in their presence (EF), for both cultivars (Fig. 1B). The interaction between earthworm and cultivar significantly affected disease severity (Table 1 ). In the EF treatment, almost no disease was observed on Aubusson plants whereas Soisson was severely affected.

\subsection{Wheat growth and resource allocation}

Almost all the variables describing wheat growth differed significantly between the two cultivars (Table 2,Fig. 2). Aubusson plants were taller (Fig. 2 A), had a greater LAI (Fig. 2 B) and a greater aerial biomass (Fig. 2C) than Soissons plants. By contrast, Soissons plants produced more tillers (Fig. 2E) and reproductive tillers (Fig. 2F) than Aubusson plants. Only root and ear biomasses did not differ significantly between the two cultivars (Table 2).

Despite effective biological control of the fungal disease (Table 1), neither total, overall aerial (Fig. 2C) nor root biomasses (Fig. 2D) were affected by eyespot inoculation (Table 2). Surprisingly, inoculation with the fungus affected only the aerial biomass of the main stem, resulting in a higher biomass than was observed in the absence of the fungus. However, significant effects were detected for specific plant organs. Comparing all the treatments with earthworms to all those without earthworms, we observed taller plants, heavier main stems (23\% increase) and greater ear production in the presence of earthworms (Table 2 and Fig. 2A). Conversely, root and tiller biomasses were greater in the absence than in the presence of earthworms. Concomitant positive effects on aboveground organs and negative effects on belowground organs accounted for the lack of an effect of earthworms on total biomass.

The allocation of biomass between the different parts of the plant was significantly affected by the presence of earthworms (Fig. 2 and Table 3): the shoot/root ratio, the main stem biomass/ tiller biomass and the ear biomass/total biomass ratios were higher in the presence than in the absence of earthworms. Ear biomass (Table 2) and main stem biomass/tiller biomass ratio (Table 3) were higher in the presence of the fungus than in its absence.

The morphology of the root system also differed between the two cultivars (Table 2) and was affected by the presence of earthworms. The presence of earthworms was associated with a lower biomass of thin roots in both cultivars, a lower biomass of thick roots in cv Soissons plants only and a lower thin/thick root ratio for both cultivars (statistics not shown in the table). Fungal inoculation had no significant effect on root architecture.

\subsection{Plant nitrogen content}

The presence of earthworms was associated with a lower root system N (Fig. 3A and Table 4) and a higher ear N (Fig. 3D) content. 

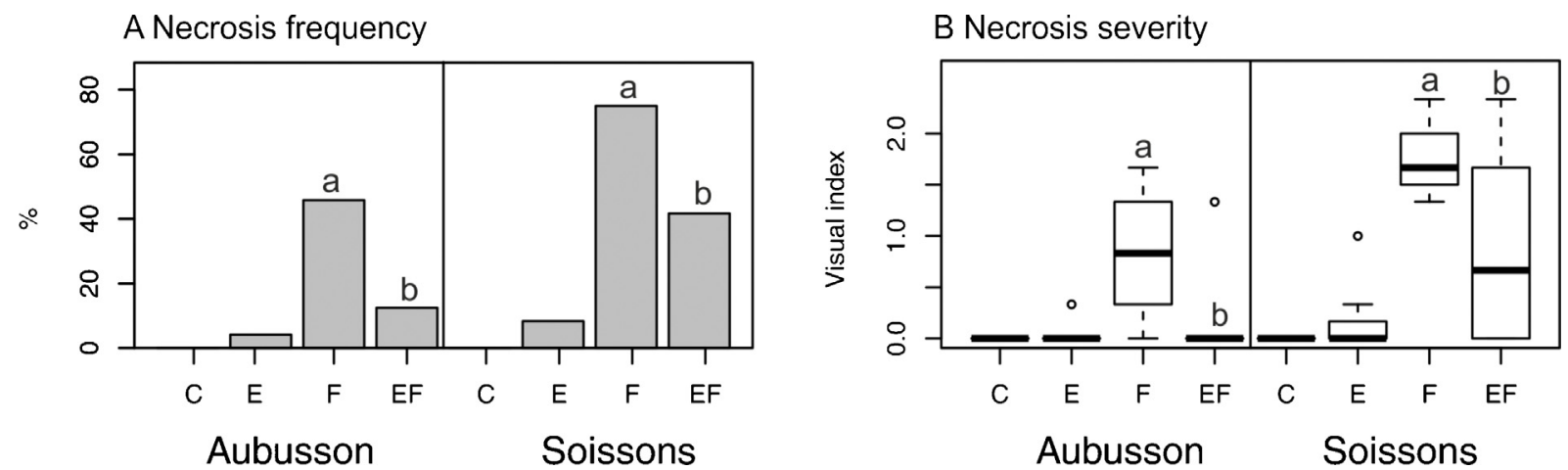

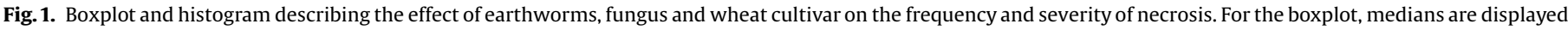

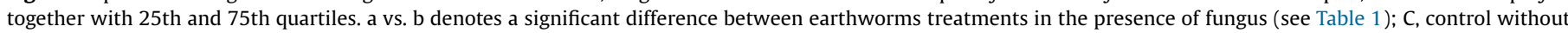
earthworm or fungus; E, earthworms; F, fungus; EF, earthworms and fungus.

Table 2

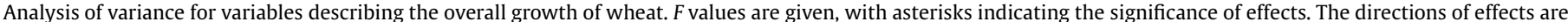

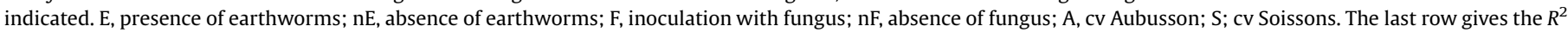

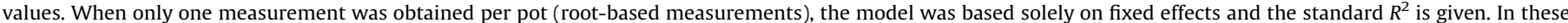

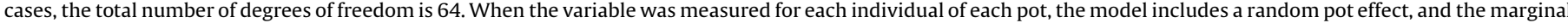
$R^{2}$ is given. In these cases, the total number of degrees of freedom is 192. - denotes interactions removed from the model because they were not significant.

\begin{tabular}{|c|c|c|c|c|c|c|c|c|c|c|c|}
\hline $\begin{array}{l}\text { Variable } \\
\text { Factor }\end{array}$ & Height & LAI & $\begin{array}{l}\text { Aerial } \\
\text { biomass }\end{array}$ & $\begin{array}{l}\text { Root } \\
\text { biomass }\end{array}$ & $\begin{array}{l}\text { Thin } \\
\text { roots } \\
< \\
400 \mu \mathrm{m}\end{array}$ & $\begin{array}{l}\text { Thick } \\
\text { roots } \\
> \\
400 \mu \mathrm{m}\end{array}$ & $\begin{array}{l}\text { Total } \\
\text { biomass }\end{array}$ & $\begin{array}{l}\text { Tiller } \\
\text { number }\end{array}$ & $\begin{array}{l}\text { Aerial } \\
\text { biomass } \\
\text { of the } \\
\text { main } \\
\text { stem }\end{array}$ & $\begin{array}{l}\text { Aerial } \\
\text { biomass } \\
\text { of tillers }\end{array}$ & Ear biomass \\
\hline Cultivar & $45.20^{* * *}$ & $42.40^{* * *}$ & $18.51^{* * *}$ & 2.69 & $15.72^{* * *}$ & $7.64^{* *}$ & $16.36^{* * * *}$ & 6. $20^{*}$ & $18.48^{* * *}$ & $4.51^{*}$ & 0.29 \\
\hline Earthworm & $13.96^{* * *}$ & 0.15 & 0.08 & $9.14^{* *}$ & $48.99^{* * *}$ & 2.00 & 0.58 & 2.60 & $11.23^{* *}$ & $7.54^{* *}$ & $19.42^{* * *}$ \\
\hline Fungus & 0.50 & 0.04 & 2.26 & 0.18 & 1.16 & 1.13 & 0.13 & 1.50 & $11.31^{* *}$ & 1.02 & $13.34^{* * *}$ \\
\hline Earthworm $\times$ cultivar & - & - & - & - & - & $4.01^{*}$ & - & - & - & - & - \\
\hline Fungus $\times$ cultivar & - & - & - & - & - & - & - & - & - & - & $4.35^{*}$ \\
\hline Direction of effects & $\begin{array}{l}A>S \\
E>n E\end{array}$ & $A>S$ & $A>S$ & $\mathrm{nE}>\mathrm{E}$ & $\begin{array}{l}A>S \\
n E>E\end{array}$ & $\begin{array}{l}A>S \\
n E>E \text { in } \\
S\end{array}$ & $A>S$ & $\mathrm{~S}>\mathrm{A}$ & $\begin{array}{l}A>S \\
E>n E\end{array}$ & $\begin{array}{l}A>S \\
n E>E\end{array}$ & $\begin{array}{l}\mathrm{E}>\mathrm{nE} \\
\mathrm{F}>\mathrm{nF} \text { (positive effect of } \mathrm{F} \\
\text { increased in } \mathrm{S} \text { ) }\end{array}$ \\
\hline$R^{2}$ & 0.49 & 0.18 & 0.09 & 0.21 & 0.38 & 0.12 & 0.28 & 0.05 & $\begin{array}{l}\mathrm{F}>\mathrm{nF} \\
0.49\end{array}$ & 0.06 & 0.43 \\
\hline
\end{tabular}

${ }^{*} P<0.05$.

${ }^{* *} P<0.01$.

${ }^{* * *} P<0.001$.

Fungal inoculation was associated with lower leaf (Fig. 3B) and stem (Fig. 3C) $\mathrm{N}$ contents. The two cultivars differed in their allocation of total nitrogen to the various parts of the wheat plant: the main stem (Fig. 3C) and ear (Fig. 3D) N contents were higher for Soissons than for Aubusson.

\subsection{Soil properties}

We found no difference in soil $C$ content between treatments (Fig. 4A and Table 5). The $\mathrm{N}$ and $\mathrm{P}$ contents of the soil were affected by the treatments. The presence of earthworms increased total soil $\mathrm{N}$ content by $8.9 \%$ (Fig. 4B) and soil nitrate content (Fig. 4C) for both cultivars. It also increased soil $\mathrm{P}$ content for Aubusson only (Fig. 4E). In the presence of earthworms, soil ammonium content was higher for Soissons (Fig. 4D). Fungal inoculation decreased soil total $\mathrm{N}$ content.

\section{Discussion}

\subsection{Eyespot symptoms and their biological control by earthworms}

Earthworm survival rate, biomass increase and cocoon production at the end of the experiment indicated that the experimental conditions were suitable for earthworms. In treatments without fungal inoculation ( $\mathrm{C}$ and $\mathrm{E}$ ), plants had almost no symptoms, so there was little risk of confusion between endemic and inoculated fungus. In treatments with fungal inoculation, disease frequency was higher for Soissons plants than for Aubusson plants. Disease severity followed a similar pattern. Therefore, under our experimental conditions, Aubusson appeared to be more resistant to eyespot than Soissons.

The biological control of eyespot by earthworms was effective for both cultivars. The difference in necrosis frequency between treatments with and without earthworms was of a similar size to the differences between the two cultivars, for both types of treatments (with and without earthworms). Furthermore, the difference in necrosis frequency between treatments with and without earthworms was similar to the difference between cultivars for the inoculated and earthworm-free treatments. As there was no significant interaction between cultivar, fungus and earthworm, we can assume that earthworms were equally effective as biological control agents on both the susceptible cultivar (Soissons) and the tolerant cultivar(Aubusson), suggesting that our results on the effect of earthworms are not cultivar-specific and can be generalized.

Our results therefore indicate that earthworms are a potentially effective biological control agent for eyespot. This finding differs from those of previous studies showing a positive effect of earthworms on the dispersal of fungal spores (Reddell and Spain, 


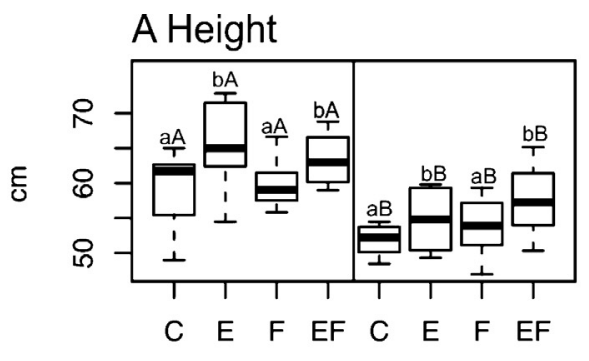

Aubusson Soissons

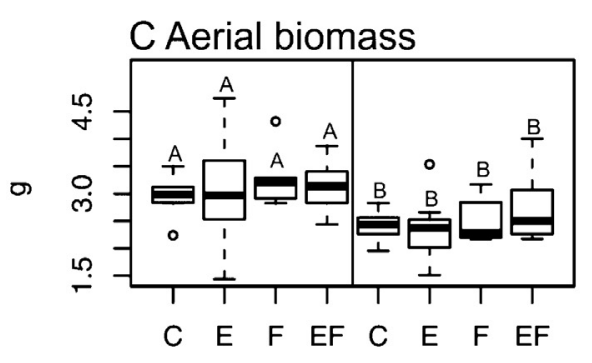

Aubusson Soissons

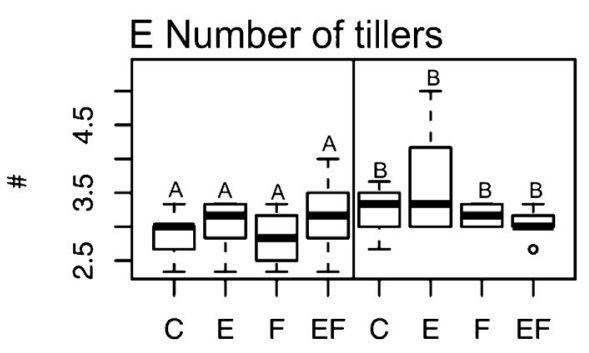

Aubusson Soissons

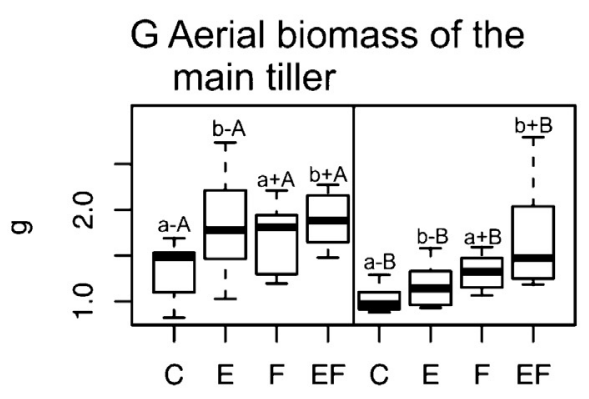

Aubusson Soissons

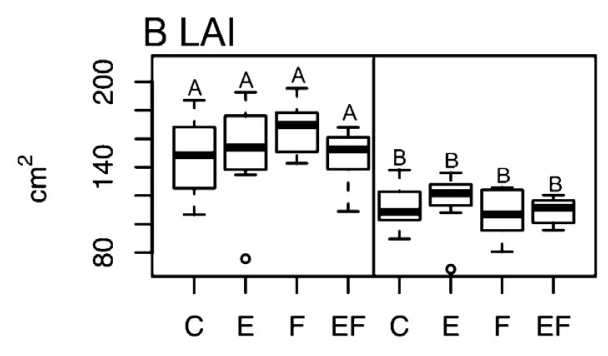

\section{Aubusson Soissons}

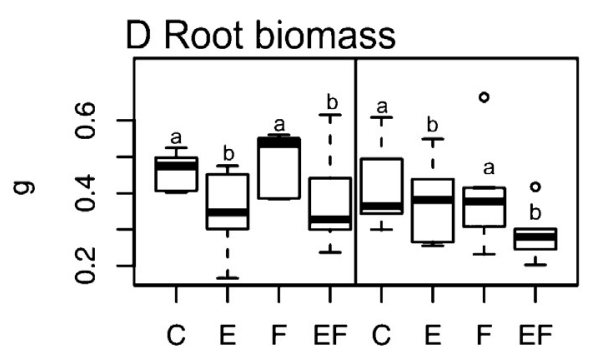

Aubusson Soissons

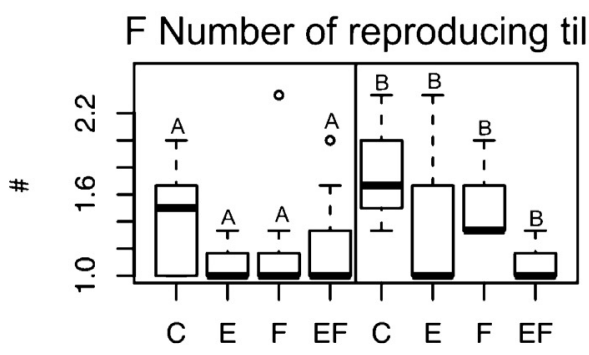

Aubusson Soissons

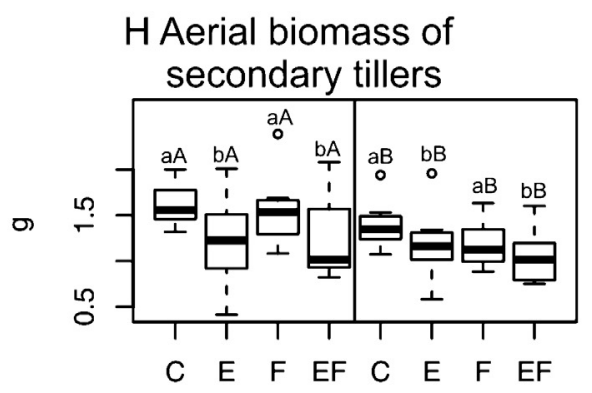

Aubusson Soissons

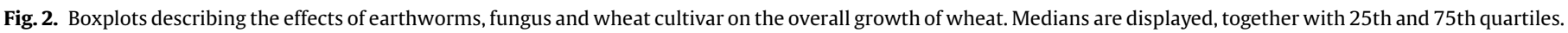

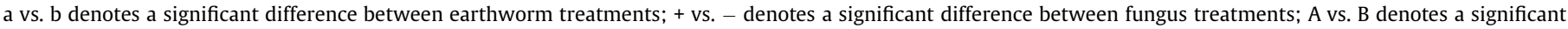
difference between cultivars. C, control without earthworm or fungus; E, earthworms; F, fungus; EF, earthworms and fungus.

1991a,b), leading to an increase in disease incidence. Our study deals with the tripartite interaction between the plant, the pathogen and the living earthworms, without considering the abundance of spores in casts, potentially accounting for this discrepancy. The lower severity of eyespot in the presence of earthworms may result from diverse mechanisms. Firstly, anecic earthworms feed on crop residues (in our case crushed barley seeds) present on the soil surface (Bouché, 1972), which they bury into the soil. Visual observations confirmed that almost all the seeds disappeared from the soil surface in the treatments with earthworms, within three days of the seeds being added to the microcosms. This burying may prevent fungal spread and plant infection. Secondly, earthworms also modify soil porosity, thereby limiting water stagnation (Blouin et al., 2007b; Jouquet et al., 2008), which would otherwise favor fungal dissemination. These two mechanisms probably account for the effect of anecic earthworms, through limitation of the amount and mobility of fungal inoculum at the soil surface. 
Table 3

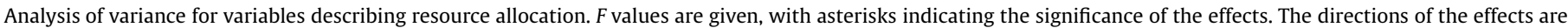

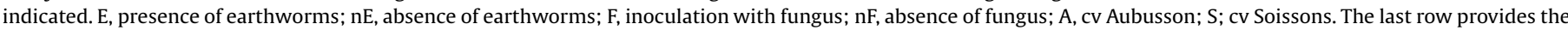

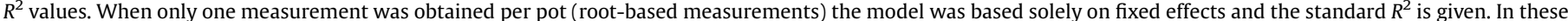

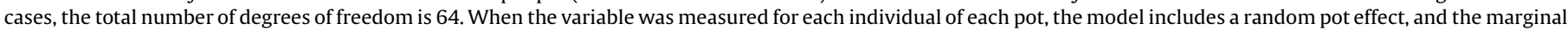
$\mathrm{R}^{2}$ is given. In these cases, the total number of degrees of freedom is 192 . - denotes interactions removed from the model because they were not significant.

\begin{tabular}{|c|c|c|c|}
\hline Factor & Shoot/root & Biomass main stem/biomass tillers & Ear biomass/total biomass (main stem) \\
\hline Cultivar & 1.26 & 0.87 & $99.00^{* * *}$ \\
\hline Earthworm & $12.58^{* * *}$ & $7.61^{* * *}$ & $3.78^{*}$ \\
\hline Fungus & 2.90 & $14.27^{* * *}$ & 0.07 \\
\hline Fungus $\times$ cultivar & - & - & - \\
\hline \multirow[t]{2}{*}{ Direction of effects } & $\mathrm{E}>\mathrm{nE}$ & $\mathrm{E}>\mathrm{nE}$ & $\mathrm{S}>\mathrm{A}$ \\
\hline & & $\mathrm{F}>\mathrm{nF}$ & $\mathrm{E}>\mathrm{nE}$ \\
\hline$R^{2}$ & 0.27 & 0.17 & 0.50 \\
\hline
\end{tabular}

${ }^{*} P<0.05$.

${ }^{* *} P<0.01$.

${ }^{* * *} P<0.001$.

A Root $\mathrm{N}$ content

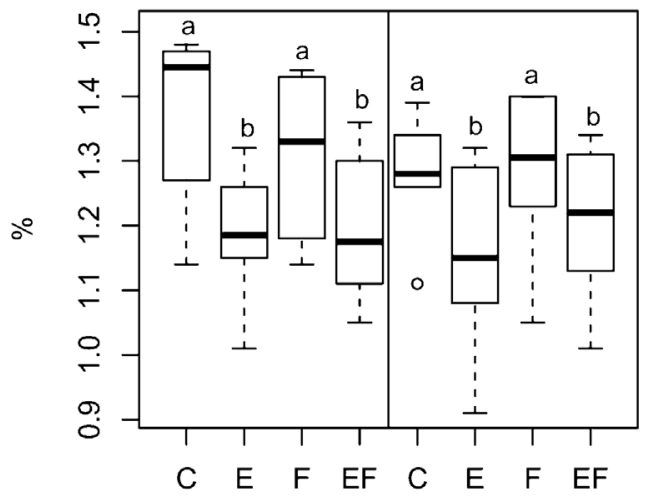

Aubusson Soissons

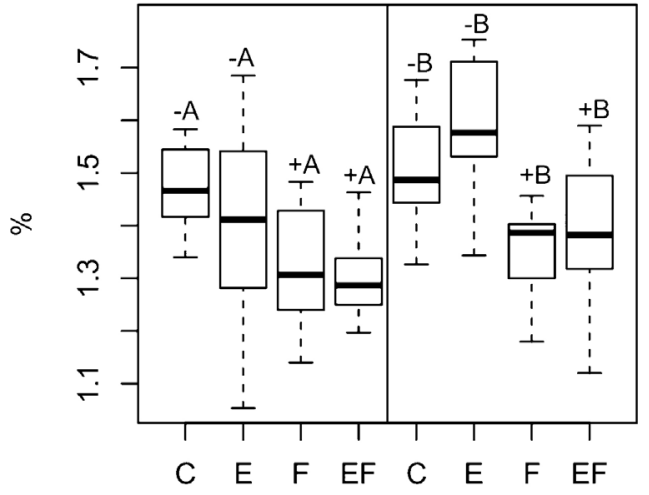

Aubusson

Soissons
B Leaf $\mathrm{N}$ content

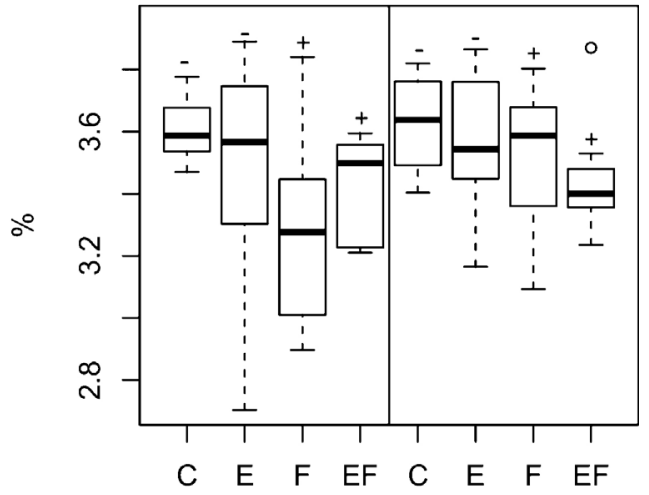

Aubusson Soissons

\section{Ear $\mathrm{N}$ content}

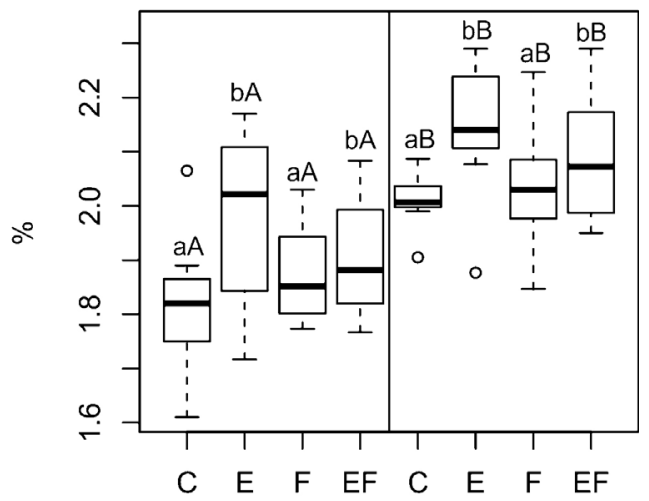

Aubusson

Soissons

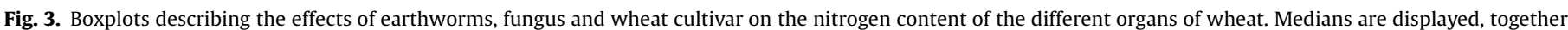

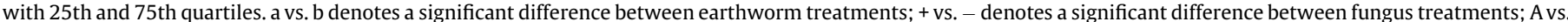
B denotes a significant difference between cultivars. C, control without earthworm or fungus; E, earthworms; F, fungus; EF, earthworms and fungus.

Thirdly, fungi are an important source of food for earthworms (Bonkowski et al., 2000; Shan et al., 2013). There is also some evidence in favor of selective feeding, with earthworms preferring pathogenic fungi over non-pathogenic fungi (Bonkowski et al., 2000). Earthworm activities are known to modify both the structure of microbial communities and the total abundance of microorganisms within their casts and in the bulk soil. This favors some micro-organisms and disadvantages others (Brown, 1995).

Finally, the lower incidence of eyespot in the presence of earthworms may also reflect the well known positive effect of earthworms on plant growth and health (Brown et al., 1999; Scheu, 
Table 4

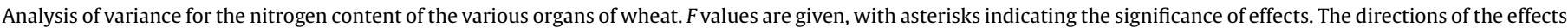

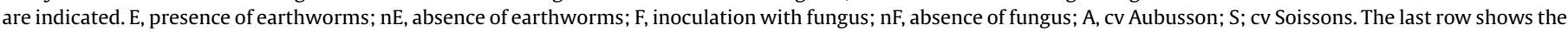

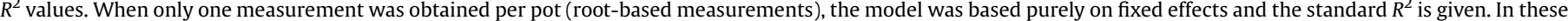

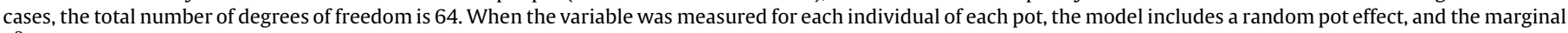
$R^{2}$ is given. In these cases, the total number of degrees of freedom is 192.

\begin{tabular}{|c|c|c|c|c|}
\hline Factor & Root N content & Leaf $\mathrm{N}$ content & Stem $\mathrm{N}$ content & Ear $\mathrm{N}$ content \\
\hline Cultivar & 1.14 & 2.60 & $6.67^{*}$ & $33.42^{* * *}$ \\
\hline Earthworm & $13.00^{* * *}$ & 0.11 & 0.00 & $8.22^{* *}$ \\
\hline Fungus & 0.00 & $6.29^{*}$ & $20.56^{* * * *}$ & 0.00 \\
\hline \multirow[t]{2}{*}{ Direction of effects } & $\mathrm{nE}>\mathrm{E}$ & $\mathrm{nF}>\mathrm{F}$ & $\mathrm{S}>\mathrm{A}$ & $\mathrm{S}>\mathrm{A}$ \\
\hline & & & $\mathrm{nF}>\mathrm{F}$ & $\mathrm{E}>\mathrm{nE}$ \\
\hline$R^{2}$ & 0.24 & 0.44 & 0.57 & 0.60 \\
\hline
\end{tabular}

${ }^{*} P<0.05$.

$P<0.01$

${ }^{* * * *} P<0.001$.

2003; Van Groenigen et al., 2014), which could prevent infection. These mechanisms are likely toact in synergy.

\subsection{Consequences for plant growth, soil nutrient availability, and $N$ allocation}

Despite marked eyespot symptoms (see above), plant growth, as assessed by measuring total, aerial and root biomasses, was not significantly affected by fungal inoculation. The experimental conditions did not seem to have favored strong development of the fungus on wheat. A larger inoculum would probably have resulted in a significant negative impact on plant biomasses. Different environmental conditions (e.g., higher soil moisture content) or experimental procedures (e.g., a different date of fungal inoculation) might also have yielded different results.
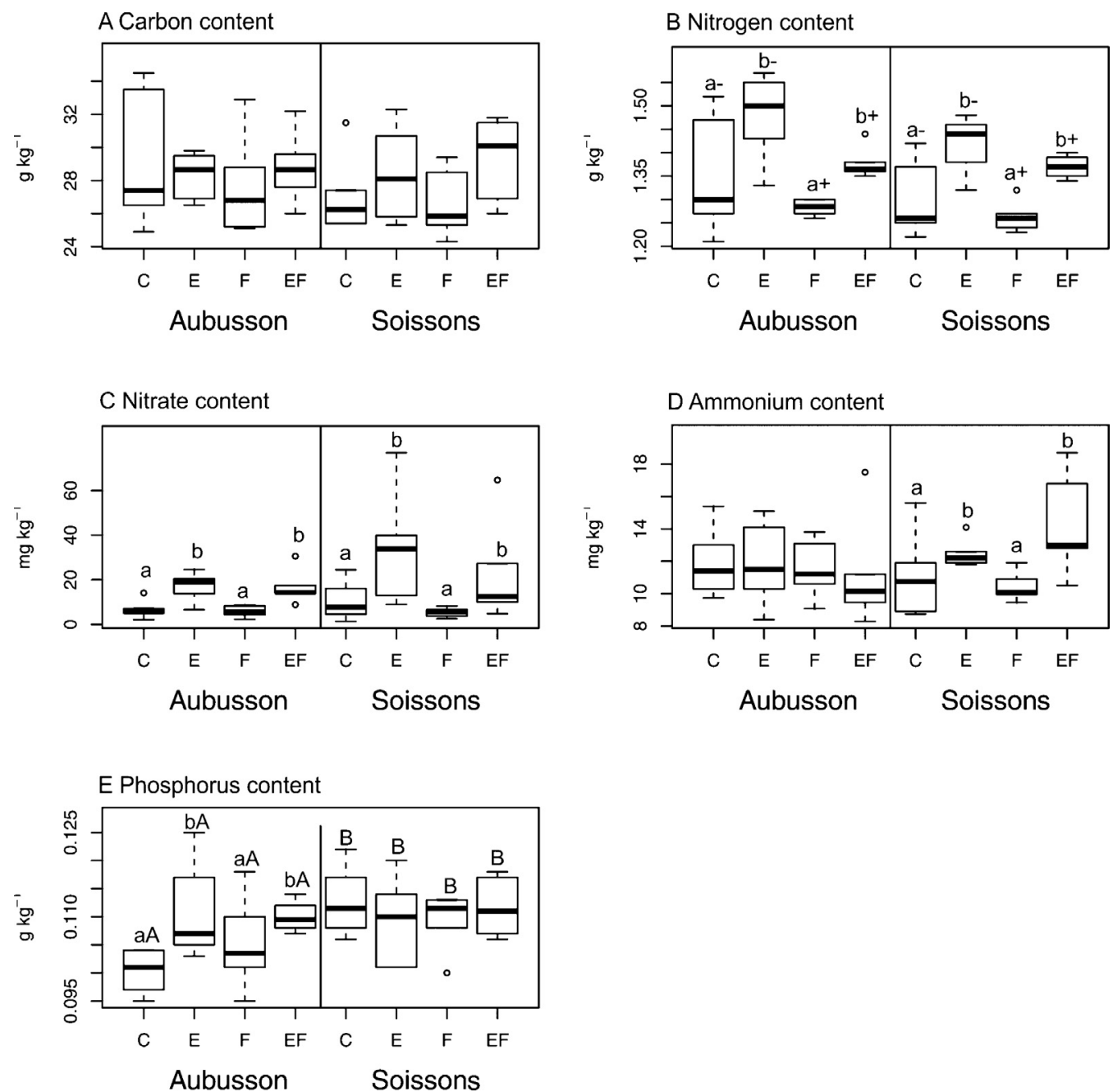

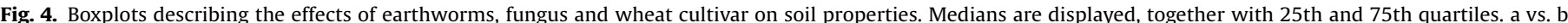

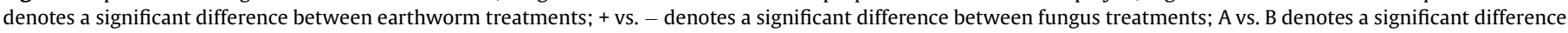
between cultivars. C, control without earthworm or fungus; E, earthworms; F, fungus; EF, earthworms and fungus. 
Table 5

Analysis of variance for soil property variables. $F$ values are given, with asterisks indicating the significance of effects. The directions of the effects are indicated. E, presence of earthworms; $\mathrm{nE}$, absence of earthworms; F, inoculation with fungus; $\mathrm{nF}$, absence of fungus; A, cv Aubusson; S; cv Soissons. The last row provides the standard $R^{2}$ values. The total number of degrees of freedom is 64 . - denotes interactions removed from the model because they were not significant.

\begin{tabular}{llllll}
\hline Factor & SOC & Total N & Nitrate & Ammonium & Phosphorus \\
\hline Cultivar & 0.65 & 3.12 & 2.90 & 0.41 & $5.69^{*}$ \\
Earthworm & 2.50 & $36.57^{* * *}$ & $17.70^{* * *}$ & 3.21 & $3.86^{*}$ \\
Fungus & 0.02 & $10.24^{* *}$ & 1.80 & 0.01 & 0.22 \\
Earthworm $\times$ cultivar & - & - & - & $4.45^{*}$ & $5.25^{*}$ \\
& & & & & \\
Direction of effects & & $\mathrm{E}>\mathrm{nE}$ & $\mathrm{E}>\mathrm{nE}$ & $\mathrm{E}>\mathrm{nE}$ in S & $\mathrm{S}>\mathrm{A}$ \\
& & $\mathrm{nF}>\mathrm{F}$ & & & $\mathrm{E}>\mathrm{nE}$ in A \\
$R^{2}$ & 0.07 & 0.54 & 0.34 & 0.16 & 0.26 \\
\hline
\end{tabular}

${ }^{*} P<0.05$.

${ }^{* *} P<0.01$.

** $P<0.001$.

In the presence of the fungus, we observed a preferential allocation of resources to the main stem, at the expense of secondary tillers. This may be interpreted as a disease resistance strategy. Indeed, it increases the likelihood of the main stem outcompeting the fungal disease through faster growth, increasing the chances of reproduction.

The presence of earthworms also affected the main stem biomass, but negatively affected root biomass, with consequences for the shoot/root ratio. The greater availability of nutrients in the presence of earthworms, due to greater organic matter mineralization, may account for the lower level of investment in root biomass (Laossi et al., 2010; Jana et al., 2010). This lower level of investment in root biomass would be expected to lead to a greater investment in aerial biomass, but no such increase was observed here. Other mechanisms, such as the modification of plant development through the release of phytohormones by bacteria activated by earthworms, may also be involved (Puga-Freitas et al., 2012a).

The differences in plant morphology and resource allocation observed in this experiment are rarely reported and often overlooked in the literature, although an in-depth analysis of these effects would make it easier to decipher the effects of earthworms on plant growth. Such an analysis would also be useful in the context of agriculture, in which the allocation of biomass to grains in cereals is a key issue. Physiologically active molecules, such as phytohormones, are good candidates for involvement in the impact of soil organisms on plant development and immunity. Earthworms are known to modify the expression of genes involved in autolysis, enabling the plant to mobilize nutrients an energy rapidly in response to stress, and that of genes involved in the biosynthesis pathway of jasmonic acid, a plant hormone controlling defense mechanisms (Blouin et al., 2005). Indole acetic acid, from the auxin family, also seems to be involved in the effect of earthworms on plants: the dwarf phenotype of an auxin-transport mutant of Arabidopsis thaliana can be converted to the wild-type phenotype in the presence of earthworms (Puga-Freitas et al., 2012b) with IAA-containing casts (Muscolo et al., 1998; Quaggiotti et al., 2004). Far from being an exception, this modification of plant immunity and development through signal molecules appears to be a common feature of soil organisms, from microorganisms, to the micro-, meso- and macro-fauna (Puga-Freitas and Blouin, 2015).

The lower concentration of $\mathrm{N}$ in plant tissues suggests that the fungus decreased the ability of the plant to take up soil mineral nutrients. However, the $\mathrm{N}$ content of the ear remained constant, possibly due to the allocation of a large proportion of $\mathrm{N}$ to the grains in response to fungal attack.
The higher soil nutrient content in the presence of earthworms can be explained by the four inputs of alfalfa litter at the soil surface, buried in the soil by L. terrestris. This would account for the higher $\mathrm{N}$ content of ears in the presence of earthworms. This positive effect of earthworms on plant $\mathrm{N}$ content has been reported in previous studies (Eisenhauer and Scheu, 2008; Jana et al., 2010; Zhang et al., 2010). We also found that root $\mathrm{N}$ content was lower in the presence of earthworms, indicating that earthworms also influence the translocation of $\mathrm{N}$ within the plant (Quaggiotti et al., 2004).

Our results suggest that earthworms favor the allocation of carbon and nitrogen to the main tiller and the ear. This effect is independent of the presence or absence of the fungus.

\section{Conclusion}

Our results show that earthworms are potentially effective biocontrol agents for eyespot, and that their presence modifies the functioning of the plant.

The positive effect of earthworms on plant growth and health (Brown et al., 1999; Scheu, 2003; Van Groenigen et al., 2014) is now well documented, and could be used in the development of alternative pest management strategies (Blouin et al., 2005; Senapati, 1992; Stephens and Davoren, 1995, 1997; Wurst et al., 2008; Wurst, 2010; Yeates, 1981). However, further investigations of the mechanisms underlying this positive effect are required, to distinguish between the effects of earthworms on pathogens and their direct effects on plants.

Our microcosm experiment suggests that crop growth conditions and yield could be increased by promoting earthworm populations. Even if microcosm experiments provide a precise characterization of infection and plant development, the results obtained can be extrapolated to the field only with extreme caution, particularly given the high earthworm density in our experiment. It would be very useful to test the control of disease by earthworms through field inoculations, to confirm the value of earthworms as biocontrol agents. Such inoculations could also facilitate the assessment of other services or disservices delivered by earthworms.

However, it is not an easy task to increase the size of earthworm populations in the field. Various strategies can be adopted (Bertrand et al., 2015), depending on the objectives of the farmer, from strategies involving minimal human intervention (such as the cessation of negative cultural practices, tillage or pesticide use or increasing the amount of organic matter returned to the soil) to strategies involving much higher levels of human intervention (use of earthworm-engineered products, such as vermicompost or vermicompost extracts), with intermediate techniques based on the inoculation of fields with earthworms or the transplantation of soil blocks (Blouin et al., 2013). Each of these techniques has been tested in only a few studies, in very different agronomic contexts, so it is not currently possible to identify the most promising techniques. There is a need for more research bringing together researchers in agronomy and soil ecology, to evaluate the most sustainable practices for increasing earthworm populations in the field.

\section{Acknowledgments}

We would like to thank the AgroParisTech Scientific Council for funding this study, and the Groupe d'Etude et de contrôle des Variétés Et des Semences (GEVES) for providing us with the fungal inoculum.

\section{References}

Altieri, M.A., 1989. Agroecology: a new research and development paradigm for world agriculture. Agric. Ecosyst. Environ. 27, 37-46. 
Anne, P., 1945. Sur le dosage rapide du carbone organique des sols. Ann. Agron. 15, $161-172$

Bardgett, R.D., Usher, M., Hopkins, D., 2005. Biological Diversity and Function in Soils. Cambridge University Press, Cambridge.

Barot, S., Lata, J.C., Lacroix, G., 2012. Meeting the relational challenge of ecological engineering. Ecol. Eng. 45, 13-23.

Bertrand, M., Barot, S., Blouin, M., Whalen, J.K., de Oliveira, T., Roger-Estrade, J., 2015. Earthworms services for cropping systems: a review. Agron. Sustainable Dev. 35, 553-567.

Blouin, M., Zuily-Fodil, Y., Pham-Thi, A., Laffray, D., Reversat, G., Pando, A., Tondoh, J., Lavelle, P., 2005. Belowground organism activities affect plant aboveground phenotype, inducing plant tolerance to parasites. Ecol. Lett. 8, 202-208.

Blouin, M., Barot, S., Roumet, C., 2007a. A quick method to determine root biomass distribution in diameter classes. Plant Soil 290, 371-381.

Blouin, M., Lavelle, P., Laffray, D., 2007b. Drought stress in rice (Oryza sativa L:) is enhanced in the presence of the compacting earthworm Millsonia anomala. Environ. Exp. Bot. 60, 352-359.

Blouin, M., Hodson, M.E., Delgado, E.A., Baker, G., Brussaard, L., Butt, K.R., Dai, J., Dendooven, L., Peres, G., Tondoh, J.E., Cluzeau, D., Brun, J.J., 2013. A review of earthworm impact on soil function and ecosystem services. Eur. J. Soil Sci. 64, 161-182.

Bonkowski, M., Griffiths, B.S., Ritz, K., 2000. Food preferences of earthworms for soil fungi. Pedobiologia 44, 666-676.

Bouché, M.B., 1972. Lombriciens de France: ecologie et systématique. INRA Ann. Zool. Ecol. Anim. France 671.

Bouché, M.B., Al-Addan, F., 1997. Role of earthworms in the N cycle: a falsifiable assessment. Soil Biol. Biochem. 29, 375-380.

Brown, G.G., 1995. How do earthworms affect microfloral and faunal community diversity? Plant Soil 170, 209-231.

Brown, G.G., Pashanasi, B., Villenave, C., Patron, J.C., Senapati, B.K., Giri, S., Barois, I. Lavelle, P., Blanchart, E., Blakemore, R.J., Spain, A.V., Boyer, J., 1999. Effects of earthworms on plant production in the tropics. In: Lavelle, P., Brussaard, L. Hendrix, P. (Eds.), Earthworm Management in Tropical Agroecosystems. CAB International, Wallingford, pp. 87-148.

Colbach, N., Meynard, J.M., Duby, C., Huet, P., 1999. A dynamic model of the influence of rotation and crop management on the disease development of eyespot. Proposal of cropping systems with low disease risk. Crop Prot. 18, 451-461.

Eisenhauer, N., Scheu, S., 2008. Earthworms as drivers of the competition between grasses and legumes. Soil Biol. Biochem. 40, 2650-2659.

Hirst, J.M., Stedman, O.J., 1962. The epidemiology of apple scab (Venturia inaequalis (Cke.). Ann. Appl. Biol. 50, 525-550.

Hooper, D.U., Bignell, D.E., Brown, V.K., Brussaard, L., Dangerfield, J.M., Wall, D.H. Wardle, D.A., Coleman, D.C., Giller, K.E., Lavelle, P., Van der Putten, W.H., De Ruiter, P.C., Rusek, J., Silver, W.L., Tiedje, J.M., Wolters, V., 2000. Interactions between aboveground and belowground biodiversity in terrestrial ecosystems: patterns, mechanisms, and feedbacks. Bioscience 50, 1049-1061.

Houba, V.J.G., Novozamsky, I., Lexmond, T.M., Van der Lee, J.J., 1990. Applicability of $0: 01 \mathrm{M} \mathrm{CaCl}_{2}$ as a single extraction solution for the assessment of the nutrient status of soils and other diagnostic purposes. Commun. Soil Sci. Plant 21, 2281 2290.

Jana, U., Barot, S., Blouin, M., Lavelle, P., Laffray, D., Repellin, A., 2010. Earthworms influence the production of above- and belowground biomass and the expression of genes involved in cell proliferation and stress responses in Arabidopsis thaliana. Soil Biol. Biochem. 42, 244-252.

Jouquet, P., Podwojewski, P., Bottinelli, N., Mathieu, J., Ricoy, M., Orange, D., Tran, T. D., Valentin, C., 2008. Above-ground earthworm casts affect water runoff and soil erosion in Northern Vietnam. CATENA 74, 13-21.

Laossi, K.R., Ginot, A., Noguera, D.C., Blouin, M., Barot, S., 2010. Earthworm effects on plant growth do not necessarily decrease with soil fertility. Plant Soil 328, 109118.

Matusinsky, P., Mikolasova, R., Klem, K., Spitzer, T., 2009. Eyespot infection risks on wheat with respect to climatic conditions and soil management. J. Plant Pathol. 91, 93-101.

Meyer, N., Lind, V., Karlovsky, P., Zahn, M., Friedt, W., Ordon, F., 2011. Development of a real-time PCR method for the identification of wheat genotypes carrying different eyespot resistance genes. Plant Breed. 130, 16-24.

Muscolo, A., Cutrupi, S., Nardi, S., 1998. IAA detection in humic substances. Soil Biol. Biochem. 30, 1199-1201.

Nakagawa, S., Schielzeth, H., O’Hara, R.B., 2013. A general and simple method for obtaining R2 from generalized linear mixed-effects models. Methods Ecol. Evol. 4, 133-142.
Puga-Freitas, R., Abbad, S., Gigon, A., Garnier-Zarli, E., Blouin, M., 2012a. Control of cultivable IAA-producing bacteria by the plant Arabidopsis thaliana and the earthworm Aporrectodea caliginosa. Appl. Environ. Soil Sci. 1, 5. doi:http://dx. doi.org/10.1155/2012/307415 Article ID 307415.

Puga-Freitas, R., Barot, S., Taconnat, L., Renou, J.-P., Blouin, M., 2012b. Signal molecules mediate the impact of the earthworm Aporrectodea caliginosa on growth, development and defence of the plant Arabidopsis thaliana. PLoS One 7, e49504 One.

Puga-Freitas, R., Blouin, M., 2015. A review of the effects of soil organisms on plant hormone signalling pathways. Environ. Exp. Bot. 114, 104-116.

Quaggiotti, S., Ruperti, B., Pizzeghello, D., Francioso, O., Tugnoli, V., Nardi, S., 2004 Effect of low molecular size humic substances on nitrate uptake and expression of genes involved in nitrate transport in maize (Zea mays L.). J. Exp. Bot. 55, 803813.

R Development Core Team, 2010. R: A Language and Environment for Statistical Computing. R Foundation for Statistical Computing, Vienna.

Scheu, S., 2003. Effects of earthworms on plant growth: patterns and perspectives. Pedobiologia 47, 846-856.

Senapati, B.K., 1992. Biotic interactions between soil nematodes and earthworms. Soil Biol. Biochem. 24, 1441-1444.

Reddell, P., Spain, A.V., 1991a. Earthworms as vectors of viable propagules of mycorrhizal fungi. Soil Biol. Biochem. 23, 767-774.

Reddell, P., Spain, A.V., 1991b. Transmission of infective Frankia (Actinomycetales) propagules in casts of the endogeic earthworm Pontoscolex corethrurus (Oligocheta: Glossoscolecidae). Soil Biol. Biochem. 23, 767-774.

Shan, J., Liu, J., Wang, Y.F., Yan, X.Y., Guo, H.Y., Li, X.Z., Ji, R., 2013. Digestion and residue stabilization of bacterial and fungal cells, protein, peptidoglycan, and chitin by the geophagous earthworm Metaphire guillelmi. Soil Biol. Biochem. 64, 9-17.

Sizmur, T., Palumbo-Roe, B., Watts, M.J., Hodson, M.E., 2011. Impact of the earthworm Lumbricus terrestris (L.) on $\mathrm{As}, \mathrm{Cu}, \mathrm{Pb}$ and $\mathrm{Zn}$ mobility and speciation in contaminated soils. Environ. Pollut. 159, 742-748.

Stephens, P.M., Davoren, C.W., Doube, B.M., Ryder, M.H., Benger, A.M., Neate, S.M., 1993. Reduced severity of Rhizoctonia solani disease on wheat seedlings associated with the presence of the earthworm Apporectodea trapezoides (Lumbricidae). Soil Biol. Biochem. 25, 1477-1484.

Stephens, P.M., Davoren, C.W., Doube, B.M., Ryder, M.H., 1994. Ability of the lumbricid earthworms Aporrectodea rosea and Aporrectodea trapezoides to reduce the severity of take-all under greenhouse and field conditions. Soil Biol. Biochem. 26, 1291-1297.

Stephens, P.M., Davoren, C.W., 1995. Effect of the lumbricid earthworm Aporrectodea trapezoides on wheat grain yield in the field, in the presence or absence of Rhizoctonia solani and Gaeumannomyces graminis var tritici. Soil Biol. Biochem. 28, 561-567.

Stephens, P.M., Davoren, C.W., 1997. Influence of the earthworms Aporrectoded trapezoides and A. rosea on the disease severity of Rhizoctonia solani on subterranean clover and ryegrass. Soil Biol. Biochem. 29, 511-516.

Van Groenigen, J.W., Lubbers, I.M., Vos, H.M.J., Brown, G., De Deyn, G.B., Van Groenigen, K.J., 2014. Earthworms increase plant production: a meta-analysis. Sci. Rep. 4, 6365.

Wardle, D.A., Bardgett, R.D., Klironomos, J.N., Setälä, H., van der Putten, W.H., Wall, D.H., 2004. Ecological linkages between aboveground and belowground biota. Science 304, 1629-1633.

Whalen, J.K., Parmelee, R.W., 2000. Earthworm secondary production and N flux in agroecosystems: a comparison of two approaches. Oecologia 124, 561-573.

Wolfarth, F., Schrader, S., Oldenburg, E., Weinert, J., Brunotte, J., 2011. Earthworms promote the reduction of Fusarium biomass and deoxynivalenol content in wheat straw under field conditions. Soil Biol. Biochem. 43, 1858-1865.

Wurst, S., 2010. Effects of earthworms on above- and below ground herbivores. Appl. Soil Ecol. 45, 123-130.

Wurst, S., Allema, B., Duyts, H., van der Putten, W.H., 2008. Earthworms counterbalance the negative effect of microorganisms on plant diversity and enhance the tolerance of grasses to nematodes. Oikos 117, 711-718.

Yeates, G.W., 1981. Soil nematode populations depressed in the presence of earthworms. Pedobiologia 22, 191-195.

Zhang, S., Chao, Y., Zhang, C., Cheng, J., Li, J., Ma, N., 2010. Earthworms enhanced winter oilseed rape (Brassica napus L.) growth and nitrogen uptake. Agric. Ecosyst. Environ. 139, 463-468. 